\title{
PAPEL DAS GESTORAS FEMININAS NA FUNÇÃO ADMINISTRATIVA DAS ESCOLAS DE GANA
}

\author{
Vera Rosemary Ankoma-Sey (PhD)*
}

\section{RESUMO}

Tradicionalmente, as mulheres, em comparação com os homens, são estereotipadas como expressivas, calorosas, gentis, tranquilas e com falta de autoconfiança; e, portanto, são vistas como tendo menos capacidade para ser líderes. Isto pôs em risco a concretização da igualdade de gênero (SDG 5), bem como a educação de qualidade (SDG 4). Este estudo examinou o nível de desempenho de diretoras mulheres em funções administrativas em escolas de Ensino Médio em Gana. Este estudo foi de natureza puramente quantitativa e empregou a concepção de Survey. 0 estudo foi delimitado em 31 escolas lideradas por diretoras mulheres. Utilizou-se o Cluster e a técnica de amostragem aleatória sistemática para selecionar os professores em cada escola. No total, 692 professores participaram do estudo. Questionários foram utilizados como instrumento de coleta de dados. 0 resultado revelou que o nível de classificação de desempenho das diretoras mulheres em papéis administrativos foi bom. Com relação à dimensão independente, as diretoras mulheres obtiveram avaliações altas. Supervisão $(M=42.34, S D=4.97)$, organização ( $\mathrm{M}=42.03, \mathrm{SD}=3.95)$ e orçamento $(\mathrm{M}=42.03, \mathrm{SD}=5.35)$ foram as funções administrativas com maior pontuação. Embora as pontuações de avaliação ( $M=41.60, S D=4.80)$, controle $(M=41.16, S D=4.65)$ e planejamento $(\mathrm{M}=40.85, \mathrm{SD}=4.53)$ tenham sido altas, estas foram menores. Resultados de Análise Multivariada de Variância One-way revelaram um teste multivariado não significativo, $F(684)=1.019$, p=.416. Isso indica que não houve diferença significativa no nível geral de desempenho de tarefas administrativas de diretoras mulheres no que diz respeito à localização da escolar. Os resultados deste estudo, portanto, indicam aos stakeholders da área de educação que permitam às mulheres a oportunidade de liderar escolas de Ensino Médio em Gana. Educação pública e sensibilização devem ser conduzidas pelo Ministério de Gênero e Assuntos Infantis para eliminar a percepção errônea por parte do público em geral em relação às mulheres que mantêm posições de direção nas escolas.

Palavras-chave: Papel administrativo; liderança feminina; planejamento; organização; direção.

* College of Distance Education, University of Cape Coast. E-mail: verasey@yahoo.com; vankomah-sey@ ucc.edu.gh 


\section{ABSTRACT \\ FEMALE HEADTEACHERS' EXECUTION OF ADMINISTRATIVE ROLES IN SENIOR HIGH SCHOOLS IN GHANA}

Traditionally, women as compared with men are stereotyped as expressive, warm, gentle, quiet and lacking confidence; and thus are seen as having less ability being leaders. This has jeopardised the realisation of gender equality (SDG 5) as well as quality education (SDG 4). This study examined the level of administrative roles performance of female headteachers in SHSs in Ghana. This study was purely quantitative in nature and employed a survey as the design. The study was limited to 31 schools which were headed by female headteachers. Cluster and systematic random sampling technique was used to sample the teachers from each school. In all 692 teachers finally participated in the study. Questionnaire was employed as a data collection tool. The result revealed that the level of performance rating of administrative roles of female headteachers were good. With regards to the independent dimension, the female headteachers were rated high. Supervision $(M=42.34, S D=4.97)$, organising ( $M=42.03, S D=3.95)$, and budgeting $(M=42.03, S D=5.35)$ were the highest rated administrative task role. Although ratings on evaluation $(\mathrm{M}=41.60, \mathrm{SD}=4.80)$, controlling $(\mathrm{M}=41.16, \mathrm{SD}=4.65)$ and planning $(M=40.85, S D=4.53)$ were high, they were least rated. Results from One-way MANOVA revealed a nonsignificant multivariate test, $F(684)=1.019, p=.416$. This indicates that there was no significant difference in the overall level of administrative task performance of female headteachers with regards to the location of school. The findings of this study therefore calls for stakeholders in education to provide women the opportunity lead in SHSs in Ghana. Public education and sensitization should be done by the Ministry of Gender and Children Affairs to remove the erroneous perception held by the general public regarding females holding positions in schools.

Keywords: Administrative role, female leadership, planning, organising, directing.

\section{RESUMEN}

\section{PAPEL DE MUJERES GERENTES EN EL PAPEL ADMINISTRATIVO DE LAS ESCUELAS DE GHANA}

Tradicionalmente, las mujeres en comparación con los hombres están estereotipadas como expresivo, cálido, suave, calma y falta de confianza; y así se ven como teniendo menos capacidad para ser líderes. Esto ha socavado la realización de la igualdad de género (SDG 5) así como la calidad de la educación (4 SDG). Este estudio analizó el desempeño de las funciones administrativas de directoras en SHSs en Ghana. Este estudio fue puramente cuantitativo en la naturaleza y ha contratado a un proyecto de investigación. El estudio fue limitado a 31 escuelas que fueron directoras. Cluster y muestreo al azar sistemático técnica fue usada para experimentar con los profesores de cada escuela. En todos los 692 maestros finalmente participar en el estudio. Cuestionario fue empleado como una herramienta de recogida de 
datos. El resultado reveló que el nivel de clasificación de rendimiento de las funciones administrativas de directoras era bueno. En cuanto a la dimensión independiente, directoras recibieron una calificación alta. Supervisión ( $\mathrm{M}=$ $42.34, \mathrm{SD}=4.97)$, organización $(\mathrm{M}=42.03, \mathrm{SD}=3.95)$ y presupuesto $(\mathrm{M}=$ $42.03, \mathrm{SD}=5,35$ ) fueron el mayor papel de la tarea administrativa. Aunque la clasificación de la calificación $(\mathrm{M}=41.60, \mathrm{SD}=4.80)$, control $(\mathrm{M}=41.16$, $\mathrm{SD}=4.65)$ y $(\mathrm{M}=40.85, \mathrm{SD}=4.53)$ eran altos, se clasificaron por lo menos. Resultados de la ida MANOVA revelaron un test multivariante incluyen respuestas significativas, $\mathrm{F}(684)=1.019, \mathrm{p}=.416$. esto indica que no hubo ninguna diferencia significativa en el nivel general de las tareas administrativas de directoras respecto de la ubicación de la escuela. Las conclusiones de este estudio, por lo tanto, las llamadas para los interesados en la educación, proporcionan a las mujeres la oportunidad de liderazgo SHSs en Ghana. Conciencia y la educación pública se realizará por el Ministerio de género y de infancia para eliminar la percepción errónea por el público en general acerca de la posición femenina en las escuelas.

Palabras clave: función administrativa, liderazgo femenino, planificación, organización, dirección

\section{INTRODUCTION}

Historically, people tend to hold the belief that leadership is a customarily male activity. Despite the increasing involvement of women in taking up leadership positions, there is still about the abilities of women in carrying leadership roles (AGEZO, 2012). It appears this has largely contributed to gender inequality. Hence, the realisation of the Sustainable Development Goal (SDG) 5 has become a challenge.

Statistics show that, globally, the total number of men approximately equals that of women. Nevertheless, gender inequality continues universally - in education, business, politics etc. This deteriorates social advancement. Equivalent opportunities for men and women fast-track achievement through other development outcomes. In the Ghanaian environment, there is little representation of women in making decision, demonstrated by 12.7 percent representation in the country's Parliament. In other cases, practices like Female Genital
Mutilation, early marriage, or witch camps are still in existence. The prevalence of violence against girls and women, and reduced access to productive possessions, such as credit and land, is still present. There are still multifaceted issues in Ghana regarding male patriarchy and supremacy that requires to be addressed to step up efforts towards the achievement of sustainable development (UN Communications Group (UNCG), Ghana, 2017).

Throughout the cultural structure in Ghana, individuals appear to stereotype men as being skilful, able to get things done, competent and aggressive; and consequently assign leadership roles to them while women are stereotyped as expressive, warm, gentle, quiet and lacking confidence; and thus are seen as having less ability being leaders (TANYE, 2008). From Eagly and Karau's (2002) view such stereotypes may have aroused from sex-role socialization during infancy. Women stereotyping perme- 
ates the Ghanaian society and consequently makes it challenging for women to be assigned to leadership roles. This situation even become worse when these women are found in rural areas where there is a lot of literates (GOTTFREDSON, 2001). These rural communities had taking an entrenched position as the supremacy of leadership at home, churches and chief palaces. Due to education, women who take up leadership position in urban areas appear to face little challenge because most people in the urban areas are literates.

During the past two eras, numerous scholars have conducted studies on gender leadership and within the scope of this study, there is an extensive body of knowledge which believe that leadership in contemporary times needs to be non-coercive, grounded on team work, and proficient at building relationships (AGEZO, 2012); and that this is the very style of leadership naturally employed by women (EAGLY; KARAU, 2002). Broadbridge (2007) also holds the view that there are gender differences in leadership and that women bring different qualities to leadership and management positions and help organizations maintain a competitive advantage. This suggests that effective school leadership not only on the part of male heads but also female headteachers is important for educational objectives to be achieved and also for the realisation of Sustainable Development Goal (SDG) 4.

Sustainable Development Goal (SDG) 4 entirely focuses on the "Education 2030" agenda. The goal, together with its corresponding targets, warrants equitable and inclusive quality education and promote lifelong learning opportunities for all. Nevertheless, school leadership plays substantial role in the realisation of the "Education 2030" agenda. Effective school leadership is essential to the development of efficiency and equity of schooling (ORGANISATION FOR ECONOMIC CO-OPERATION AND DEVELOPMENT, 2018). Vvob (2018) makes it clear that school leaders is vital in providing conditions for effective teaching and learning. No country can improve the educational quality in the absence of effective school leadership (VVOB, 2018). It is essential for major stakeholders to ensure female headteachers are given equal opportunity and environment to exhibit their capabilities geared towards quality education.

Although the perceptions held by Ghanaians about female leadership speaks to the notion that they are incapable of performing effectively as school heads, studies conducted outside Ghana show otherwise. Bass and Avolio (1994), for one, found that female leaders performed significantly higher than male on numerous standards considered perilous to swiftly changing learning institutions. The women leaders were highly rated than men in inspirational motivation, idealized influence, individual consideration, and intellectual stimulation, leading in more effective subordinates who uttered greater satisfaction in the place of work. Likewise, Ngcobo (1996), who assessed the perception of teachers' of female leaders and reported that female leaders were preferred for principal positions because they were efficient organizers, had good relationship with staff, were self-discipline, were democratic leaders and had the capacity to initiate positive change. Lad (2000) also revealed that female principals were better than males in the area of evaluating and supervising instruction, communicating school goals, maintaining high visibility, coordinating curriculum, providing incentives for learning and promoting professional development. Will these findings be 
different when similar study is conducted in Ghana? Are the perceptions held the Ghanaian public about women ineffectiveness in leadership true? These are mind boggling questions this study seeks to address. This study aims at exploring the level of administrative roles performance of female headteachers in SHSs in Ghana.

\section{RESEARCH QUESTIONS}

Two questions drove the entire study:

1. What is the level of performance of administrative roles of female headteachers in SHSs in Ghana?

2. What differences exist in the level of performance of administrative roles of female headteachers in SHSs in Ghana with regards to school location?

\section{METHODS}

This study was purely quantitative in nature and employed a survey as the design. The study covered all teachers in the Senior High Schools in Ghana. Particularly, schools with female headteachers were purposively chosen. The study was limited to 31 schools which were headed by female headteachers. Cluster and systematic random sampling technique was used to sample the teachers from each school. In all 692 teachers finally participated in the study. These participants were required to rate their headteachers (which were only females) regarding their performance of their administrative task performance. The data was gathered with the help of trained and recruited 10 research assistants. All protocols were observed during the data collection. Questionnaire was employed as a data collection tool. On the instrument, administrative tasks were measured using six dimensions namely, planning, organising, directing, supervising, evaluating, controlling and budgeting. Each of the dimensions had 10-items which the teachers were required rate their female headteachers on a scale of 1-5 where higher scores indicates better performance. An initial pre-test data was taken to ensure accuracy of results. Again, Cronbach Alpha Reliability estimates revealed a reliability values ranging from .71 to .89 , which were acceptable. The data was analysed using means and standard deviation. This analysis addressed the first objective of the study. One-way Multivariate Analysis of Variance (MANOVA) was conducted to examine whether differences exist in the performance of administrative roles of female headteachers with regards to school location. MANOVA was used because administrative tasks rating was on seven hypothetical dimensions. While the multivariate test used an alpha level of .05, the univariate results was interpreted using a Bonferroni adjusted alpha level of .007 which controlled for the risk of Type 1 error. Prior to the analysis, all assumptions were checked and were met.

\section{FINDINGS}

\section{FEMALE HEADTEACHERS}

\section{LEVEL OF PERFORMANCE OF}

\section{ADMINISTRATIVE ROLES IN SHSS IN GHANA}

Ratings on all the dimensions ranged from 10-50. A criterion mean of 30.0 was used as the benchmark. Scores above the criterion mean indicated good level of performance of administrative roles of female headteachers. Mean scores below the criterion mean showed poor level of performance of administrative roles of female headteachers. 
Table 1: Level of Performance of Administrative Roles of Female Headteachers in SHSs in Ghana

\begin{tabular}{|l|c|c|c|c|}
\hline Dimensions & Mean & Std. Dev & Ratings & Remarks \\
\hline Supervising & 42.34 & 4.97 & $1^{\text {st }}$ & Good \\
\hline Organising & 42.03 & 3.95 & $2^{\text {nd }}$ & Good \\
\hline Budgeting & 42.03 & 5.35 & $3^{\text {rd }}$ & Good \\
\hline Directing & 41.74 & 4.82 & $4^{\text {th }}$ & Good \\
\hline Evaluating & 41.60 & 4.80 & $5^{\text {th }}$ & Good \\
\hline Controlling & 41.16 & 4.65 & $6^{\text {th }}$ & Good \\
\hline Planning & 40.85 & 4.53 & $7^{\text {th }}$ & Good \\
\hline Overall & 41.69 & 3.73 & - & Good \\
\hline
\end{tabular}

The result revealed that the level of performance rating of administrative roles of female headteachers were good. With regards to the independent dimension, the female headteachers were rated high. Supervision $(M=42.34, S D=4.97)$, organising $(M=42.03$, $S D=3.95)$, and budgeting $(M=42.03, S D=5.35)$ were the highest rated administrative task role. Although ratings on evaluation $(M=41.60, S D=4.80)$, controlling $(M=41.16$, $S D=4.65)$ and planning $(M=40.85, S D=4.53)$ were high, they were least rated.

\section{SCHOOL LOCATION AND FEMALE HEADTEACHERS LEVEL OF PERFORMANCE OF ADMINISTRATIVE ROLES IN SHSS IN GHANA}

One-way MANOVA was used to find out whether there are differences in the administrative task performance of female headteachers in rural schools and those in urban schools.

Table 2: Multivariate Test

\begin{tabular}{|c|l|c|c|c|c|}
\hline \multicolumn{1}{|c|}{ Effect } & Value & F & df & Sig. \\
\hline \multirow{5}{*}{ Intercept } & Pillai's Trace & .985 & $6612.740^{\mathrm{b}}$ & 684.000 & .000 \\
\cline { 2 - 6 } & Wilks' Lambda & .015 & $6612.740^{\mathrm{b}}$ & 684.000 & .000 \\
\cline { 2 - 6 } & Hotelling's Trace & 67.674 & $6612.740^{\mathrm{b}}$ & 684.000 & .000 \\
\cline { 2 - 6 } & Roy's Largest Root & 67.674 & $6612.740^{\mathrm{b}}$ & 684.000 & .000 \\
\hline \multirow{5}{*}{ School location } & Pillai's Trace & .010 & $1.019^{\mathrm{b}}$ & 684.000 & .416 \\
\cline { 2 - 6 } & Wilks' Lambda & .990 & $1.019^{\mathrm{b}}$ & 684.000 & .416 \\
\cline { 2 - 6 } & Hotelling's Trace & .010 & $1.019^{\mathrm{b}}$ & 684.000 & .416 \\
\cline { 2 - 6 } & Roy's Largest Root & .010 & $1.019^{\mathrm{b}}$ & 684.000 & .416 \\
\hline
\end{tabular}

The result, as shown in Table 2, shows a nonsignificant multivariate test, $F(684)=1.019, p=.416$. This indicates that there was no significant difference in the overall level of administrative task performance of female headteachers with regards to the location of school.

Consistent with the multivariate finding, 
result from the univariate test (Table 3) also [p=.290], supervising [p=.139], evaluating found no significant difference in the di- $[p=.165]$, controlling [p=.992] and budgetmensions of administrative tasks (planning ing [p=.295]) between female headteachers $[p=.552]$, organising $[p=.593]$, directing in rural schools and those in urban schools.

Table 3: Univariate Test

\begin{tabular}{|c|c|c|c|c|c|c|}
\hline Source & $\begin{array}{l}\text { Dependent } \\
\text { Variable }\end{array}$ & $\begin{array}{l}\text { Type III Sum } \\
\text { of Squares }\end{array}$ & $\mathrm{df}$ & Mean Square & $\mathrm{F}$ & Sig. \\
\hline \multirow{7}{*}{$\begin{array}{l}\text { Corrected } \\
\text { Model }\end{array}$} & Planning & $7.269^{\mathrm{a}}$ & 1 & 7.269 & .354 & .552 \\
\hline & Organising & $4.473^{\mathrm{b}}$ & 1 & 4.473 & .286 & .593 \\
\hline & Directing & $26.028^{c}$ & 1 & 26.028 & 1.122 & .290 \\
\hline & Supervising & $54.038^{\mathrm{d}}$ & 1 & 54.038 & 2.195 & .139 \\
\hline & Evaluating & $44.519^{\mathrm{e}}$ & 1 & 44.519 & 1.933 & .165 \\
\hline & Controlling & $.002^{\mathrm{f}}$ & 1 & .002 & .000 & .992 \\
\hline & Budgeting & $31.405^{\mathrm{g}}$ & 1 & 31.405 & 1.099 & .295 \\
\hline \multirow{7}{*}{ Intercept } & Planning & 564392.934 & 1 & 564392.934 & 27500.060 & .000 \\
\hline & Organising & 592205.630 & 1 & 592205.630 & 37853.957 & .000 \\
\hline & Directing & 580725.727 & 1 & 580725.727 & 25027.863 & .000 \\
\hline & Supervising & 595082.223 & 1 & 595082.223 & 24173.989 & .000 \\
\hline & Evaluating & 575145.005 & 1 & 575145.005 & 24976.419 & .000 \\
\hline & Controlling & 570076.488 & 1 & 570076.488 & 26356.156 & .000 \\
\hline & Budgeting & 588362.966 & 1 & 588362.966 & 20582.809 & .000 \\
\hline \multirow{7}{*}{$\begin{array}{l}\text { School } \\
\text { location }\end{array}$} & Planning & 7.269 & 1 & 7.269 & .354 & .552 \\
\hline & Organising & 4.473 & 1 & 4.473 & .286 & .593 \\
\hline & Directing & 26.028 & 1 & 26.028 & 1.122 & .290 \\
\hline & Supervising & 54.038 & 1 & 54.038 & 2.195 & .139 \\
\hline & Evaluating & 44.519 & 1 & 44.519 & 1.933 & .165 \\
\hline & Controlling & .002 & 1 & .002 & .000 & .992 \\
\hline & Budgeting & 31.405 & 1 & 31.405 & 1.099 & .295 \\
\hline \multirow{7}{*}{ Error } & Planning & 14161.101 & 690 & 20.523 & & \\
\hline & Organising & 10794.694 & 690 & 15.644 & & \\
\hline & Directing & 16010.186 & 690 & 23.203 & & \\
\hline & Supervising & 16985.477 & 690 & 24.617 & & \\
\hline & Evaluating & 15888.989 & 690 & 23.028 & & \\
\hline & Controlling & 14924.512 & 690 & 21.630 & & \\
\hline & Budgeting & 19723.763 & 690 & 28.585 & & \\
\hline
\end{tabular}




\section{DISCUSSION}

The findings revealed that the performance of administrative roles of female headteachers in Ghana were rated high. Further analysis showed that female headteachers in rural schools and those in urban schools both performed equally in terms of performing their administrative functions. This trend of result is good due to the fact that once female headteachers are doing well, our educational system drives towards attainment of quality education. The result also debunk the cultural perceptions held by the general public regarding seeing only men as being skilful, able to get things done, competent and aggressive; and consequently assign leadership roles to them while women are stereotyped as expressive, warm, gentle, quiet and lacking confidence; and thus are seen as having less ability being leaders (TANYE, 2008). I agree with Ngcobo (1996), who evaluated the perception of teachers' of female leaders and reported that female leaders were preferred in holding the principal position because they were efficient organizers, had good relationship with staff, were self-discipline, were democratic leaders and had the capacity to initiate positive change. It is not surprising that Lad (2000) also revealed that female principals were better than males in the area of evaluating and supervising instruction, communicating school goals, maintaining high visibility, coordinating curriculum, providing incentives for learning and promoting professional development. It is important for women to be also involved in leadership since they are also capable of performing well on their jobs. This study, however, do not suggest that females perform better than male headteachers since no empirical comparison was made. Involving women in leadership do not only help achieve quality education but also promote gender equality which leads to sustainable development of every nation.

\section{CONCLUSION AND RECOMMENDATIONS}

The study concludes that women and not only men have the ability to effectively handle leadership positions in SHSs in Ghana. It is not out of way to state that women have the competencies, abilities and skills in leadership. It must be emphasised that while giving women opportunities to improve the quality of education, it also help promote gender equality in leadership.

The findings of this study therefore calls for stakeholders in education to provide women the opportunity lead in SHSs in Ghana. Public education and sensitization should be done by the Ministry of Gender and Children Affairs to remove the erroneous perception held by the general public regarding females holding positions in schools. This is because this study together with other international studies have provided evidence that women can hold effectively hold leadership positions when given the opportunity.

\section{REFERENCES}

AGEZO, K. C. Female leadership and school effectiveness in junior high schools in Ghana. Journal of Educational Administration, 48(6), 689-703, 2010.

BASS, B. M., \& Avolio, B. J. Transformational leadership and organizational culture. International Journal of Public Administration, 17(3/4), 541-54, 1994.

BROADBRIDGE, A. Retailing: dominated by women; managed by men. International Journal of Retail \& Distribution Management, 35, 12-21, 2007.

EAGLY, A. H., \& Karau, S. J. (2002). Role ambiguity theory of prejudice toward female leaders. 
Psychological Review, 109(3), 573-98, 2002.

GOTTFREDSON, D. C. Schools and delinquency. Cambridge: Cambridge University Press, 2001.

LAD, K. Two women high school principals: the influence of gender on entry into education and their professional lives. Journal of School Leadership, 12, 663-89, 2000.

NGCOBO, T.M. An investigation into teachers' perceptions of female secondary school principals in Kwazulu Natal. Unpublished master's thesis, Rhodes University, Grahams town, 1996.

ORGANISATION FOR ECONOMIC CO-OPERA-
TION AND DEVELOPMENT. School leadership, 2018. Retrieved from www.vvob.com.

TANYE, M. Access and barriers to education for Ghanaian women and girls. Interchange, 39(2), 167-84, 2008.

UN COMMUNICATIONS GROUP (UNCG). Gender inequality in Ghana, SDG 5. Accra: UN Communications Group (UNCG) Press, 2017.

VVOB (2018). Putting SDG\$ into practice. Technical Brief, 1, 1-11, 2018.

Recebido em: 19/02/2019

Aprovado em: 06/05/2019 